Elsevier/North-Holland Biomedical Press

BBA 79449

\title{
LATENT ACETYLCHOLINESTERASE IN SECRETORY VESICLES ISOLATED FROM ADRENAL MEDULLA
}

\author{
MANFRED GRATZL, HEIDEMARIE KRIEGER-BRAUER and ROLAND EKERDT * \\ Department of Phystological Chemistry, University of Saarland, D-665 Homburg/Saar (F.R.G.)
}

(Received May 12th, 1981)

Key words. Acetylcholinesterase, Secretory vesicle, (Adrenal medulla, Bovine)

A new procedure is described for the preparation of highly purified and stable secretory vesicles from adrenal medulla. Two forms of acetylcholinesterase, a membrane bound form as well as a soluble form, were found within these vesicles. The secretory vesicles, isolated by differential centrifugation, were further purified on a continuous isotonic Percoll ${ }^{\mathrm{TM}}$ gradient. In this way, secretory vesicles were separated from mitochondrial, microsomal and cell membrane contamination. The secretory vesicles recovered from the gradient contained an average of $2.26 \mu \mathrm{mol}$ adrenalin $/ \mathrm{mg}$ protein. On incubation for $30 \mathrm{~min}$ at $37^{\circ} \mathrm{C}$ in media differing in ionic strength, $\mathrm{pH}$, $\mathrm{Mg}^{2+}$ and $\mathrm{Ca}^{2+}$ concentration, the vesicles released less than $20 \%$ of total adrenalin. Acetylcholinesterase could hardly be detected in the secretory vesicle fraction when assayed in isotonic media. However, in hypotonic media $(<400 \mathrm{mosmol} / \mathrm{kg})$ or in Triton X-100 (0.2\% final concentration) acetylcholinesterase activity was markedly higher. During hypotonic treatment or when secretory vesicles were specifically lyzed with $2 \mathrm{mM} \mathrm{Mg}^{2+}$ and $2 \mathrm{mM}$ ATP, adrenalin as well as part of acetylcholinesterase was released from the vesicular content. On polyacrylamide gel electrophoresis this soluble enzyme exhibited the same electrophoretic mobility as the enzyme released into the perfusate from adrenal glands upon stimulation. In addition to the soluble enzyme a membrane bound form of acetylcholinesterase exists within secretory vesicles, which sediments with the secretory vesicle membranes and exhibits a different electrophoretic mobility compared to the soluble enzyme. It is concluded, that the soluble enzyme found within isolated secretory vesicles is secreted via exocytosis, whilst the membrane-bound form is transported to the cell membrane during this process, contributing to the biogenesis of the cell membrane.

\section{Introduction}

During exocytosis secretory vesicles become inserted into the cell membrane and the vesicle contents are released into the extracellular fluid. This suggests that membrane and secreted proteins are transported to the cell membrane via a common

\footnotetext{
* Present address. Cancer Research Institute, University of Calıfornia, SF, San Francisco, CA 94143, U.S.A.

Abbreviations: DNTB, dithiobis(2-nitrobenzo1c acid), EGTA, ethyleneglycol bis( $\beta$-amino-ethyl ether)- $N, N^{\prime}$-tetraacetic acid; Hepes, $\quad N$-2-hydroxyethylpiperazine- $N^{\prime}$-2-thane-sulphonic acid; Mes, 2-( $N$-morpholino)ethanesulphonic acid; Mops, 3-( $N$-morpholıno)propanesulphonic acid; TEMED, $N, N, N^{\prime}, N^{\prime}$ tetramethylethylenediamine.
}

pathway [1]. Acetylcholinesterase, in the chromaffin cells of adrenal medulla, exists in both a membranebound form and a secreted form (cf. Refs. 2-4). Whether or not both forms are actually present in secretory vesicles of chromaffin cells as precursors of the species secreted or that associated with the outer leaflet of the cell membrane of the chromaffin cell was as yet unknown.

Studies of the composition and properties of adrenal medullary secretory vesicles have hitherto been hampered by the fragility of isolated secretory vesıcles, especially when further purified on sucrose density gradients. Because of this reason, only 'crude' (1.e. obtained by differential centrifugation) secretory vesicles from adrenal medulla were used recently 
for the determination of the sidedness of membrane proteins $[5,6]$.

In this work we report the isolation of highly purified adrenal medullary secretory vesicles by differential and density gradient centrifugation using isotonıc gradient material (Percoll ${ }^{\mathrm{TM}}$ ). The vesicles were remarkably stable compared to vesicles prepared on sucrose gradients. Acetylcholinesterase was latent in the isolated secretory vesicles, i.e. the enzyme was inacessible to added substrate, but a marked increase in activity was found when the vesicles were lyzed. The vesicles contain two types of acetylcholinesterase, one type is membrane bound but faces the intravesicular space, the other type is part of the vesicular content. The latter exhibits the same electrophoretic mobility as the enzyme released by adrenal glands into the perfusate upon stımulation. The colocation of membrane-bound and secreted acetylcholinesterase within secretory vesicles supports the hypothesis that the two molecular forms are transported to the cell membranes via the exocytotic pathway.

Preliminary reports of parts of this work have appeared elsewhere $[7,8]$.

\section{Materials and Methods}

\section{Isolation of secretory vesicles}

Bovine adrenal glands were obtained at the slaughterhouse. They were kept in an icecold medium $(0.15$ $\mathrm{M}$ sodium chloride, $5 \mathrm{mM}$ Hepes, $5 \mathrm{mM}$ EDTA, $\mathrm{pH}$ 7.0) and where transported to the laboratory within $2 \mathrm{~h}$ after death of the animals. The medullae were cut out and placed into a medium containing $20 \mathrm{mM}$ Mops, pH 7.0 (adjusted with $\mathrm{NaOH}$ ), 5 mM EDTA and $0.34 \mathrm{M}$ sucrose to give a final osmolality of about $420 \mathrm{mosmol} / \mathrm{kg}$ (isolation medium). All fractionation procedures were carefully carried out in the cold $\left(0-5^{\circ} \mathrm{C}\right)$.

The medullae were chopped into small preces using scissors. Homogenization of the mince ( $48 \mathrm{~g}$ tissue in $240 \mathrm{ml}$ isolation medium) was performed in a loosefitting Teflon-to-glass homogenizer by three downward strokes. The homogenate was centrifuged at $2200 \times g_{a v}$ for $10 \mathrm{~min}$. The pellet $\mathrm{P}_{1}$ was resuspended in $80 \mathrm{ml}$ isolation medium. The supernatant $S_{1}$ was filtered through two layers of cheesecloth and made up to $240 \mathrm{ml}$ with isolation medium. After centr1fugation at $12000 \times g_{\text {av }}$ for $20 \mathrm{~min}$ a pellet of crude secretory vesicles $\left(\mathrm{P}_{2}\right)$ and a supernatant $\left(\mathrm{S}_{2}\right)$ was obtained. $S_{2}$ was centrifuged at $100000 \times g_{a v}$ for 60 min to sediment microsomes $\left(\mathrm{P}_{3}\right)$. Aliquots of cell fractions, including the clear final supernatant $S_{3}$ were kept for analysis.

$50 \mathrm{ml} \mathrm{Percoll}^{\mathrm{TM}}$ (density $1.132 \mathrm{~g} / \mathrm{ml}$ ) was dialyzed twice for $7 \mathrm{~h}$ against 11 ssolation medium. The volume of the dialyzed Percoll was made up to $100 \mathrm{ml}$ with isolation medium. The pellet $P_{2}$ (obtained from $48 \mathrm{~g}$ tissue mince) was resuspended in $8 \mathrm{ml}$ isolationmedium and mixed with $72 \mathrm{ml}$ Percoll prepared as described above. The mixture was put into $9 \mathrm{ml}$ tubes and centrifuged at $35000 \times g_{\text {av }}$ for $30 \mathrm{~min}$ using a fixed angle Kontron TFT 65.13 rotor with the brake on.

After centrifugation about 40 fractions were collected from each tube. Fractions 1-18 (starting from the bottom of the tube) were pooled, as were the remaining fractions. The pools were diluted $1: 5$ with isolation medium and centrifuged at $100000 \times$ $g_{\mathrm{av}}$ for $35 \mathrm{~min}$. In this way the subcellular fractions were concentrated as a band above a cushion of Percoll and were removed by means of a syringe. The material onginating from fractions 1.18 (secretory vesicles, fraction SV) and that from the remaining fractions (mainly mitochondria, fraction $R$ ) was resuspended in a small volume of isolation medium. If desired traces of Percoll were removed from fractions SV and R using a Biogel column (A 150, 100-200 mesh) equilibrated with isolation medium (contaning $1 \mathrm{mM}$ EGTA instead of $5 \mathrm{mM}$ EDTA). Fraction SV was then concentrated by centrifugation $\left(12000 \times g_{\text {av }}\right.$, for $\left.20 \mathrm{~min}\right)$. Secretory vesicles ghosts were obtained by diluting fraction SV in a 10 -fold excess for $20 \mathrm{mM}$ Mops, pH 7.0, $5 \mathrm{mM}$ EDTA and harvesting by centrifugation at $100000 \times g_{\text {av }}$ for 60 min at $4^{\circ} \mathrm{C}$. The pellet was resuspended in $20 \mathrm{mM}$ Mops, $\mathrm{pH} 7.0,5 \mathrm{mM}$ EDTA and recentrifuged (twice).

\section{Stability of the isolated secretory vesicles}

To investigate the stability of secretory vesicles, concentrated fraction SV was diluted 10-fold in media of reduced or increased osmolality (by omission or addition of sucrose), in media of different $\mathrm{pH}$ (pH 6.0 and 6.5 buffered with Mes, pH 7.5 and 8.0 with Hepes) or in media containing different concentrations of monovalent or divalent cations. After 
incubation the mixtures were centrifuged for $5 \mathrm{~min}$ in a Model 3200 Eppendorf centrifuge or for $10 \mathrm{~min}$ in a Beckman Airfuge ${ }^{\mathrm{TM}}\left(130000 \times g_{\text {av }}\right)$ and samples from the supernatant were taken for determination of adrenalin, protein or acetylcholinesterase released.

\section{Analytical procedures}

Protein was determined [9] by precipitating the samples with trichloroacetic acid (10\%) and dissolving the protein pellet with desoxycholate/sodium hydroxide $(2 \% / 3 \%)$. The trichloroacetic acid supernatants were used for the determination of ascorbate and catecholamines. Adrenalin and noradrenalın were measured by the formation of fluorescent trihydroxyindole derivatives [10]. After removal of the catecholamines by adsorption to DOWEX $50 \mathrm{~W}-\mathrm{X} 8$ [11], ascorbate was assayed by 1 ts reduction of 2,6-dichlorphenolindophenol at $\mathrm{pH} 4.1$ in $0.75 \mathrm{M}$ citrate/acetate buffer [12]. Glutamate dehydrogenase, an enzyme marker for the mitochondrial matrix was determined as described [13] in the presence of $0.1 \%$ Triton $\mathrm{X}-100$ [14], $1 \mathrm{mM}$ leucine and $1 \mathrm{mM}$ ADP. Glucose6-phosphatase [14] served as a marker for membranes orginating from the endoplasmic reticulum. The inorganic phosphate released was determined [15]. Acetylcholinesterase, often used as a marker for cell membranes in subfractionation studies of the adrenal medulla, was assayed with acetylthiocholine as a substrate [16] in isolation medium in the presence of $0.2 \%$ Triton X-100. Detergent was omitted where indicated. In hypotonic media acetylcholinesterase activity was measured in the dual wavelength mode $(412 \mathrm{~nm} / 450 \mathrm{~nm}$ ) (see Fig. 4). The enzyme activity in subcellular fractions from adrenal medulla was inhibited by $95 \%$ when $5 \mu \mathrm{M}$ BW 284C51 (dimethobromide of 1,5 -dı( $p-N$-allyl- $N$-methylaminophenyl)pentane-3-one) was present. The enzyme activities given therefore represent true acetylcholinesterase. Lactate dehydrogenase was measured in the presence of $0.3 \%$ Triton X-100 by following the oxidation of NADH at $340 \mathrm{~nm}[17]$.

\section{Polyacrylamide gel electrophoresis}

Samples for electrophoresis were prepared in 62.5 $\mathrm{mM}$ Tris- $\mathrm{HCl}$ (pH 6.8) containing $0.5 \%$ Triton X-100, $10 \%$ glycerol and $0.002 \%$ bromphenol blue as a tracking dye. Slab gel electrophoresis [18] was carned out using an $8 \%$ acrylamide $\left(0.16 \% N, N^{\prime}\right.$-methylene-bisacrylamide) separation gel in Tris- $\mathrm{HCl}(375 \mathrm{mM}$,
pH 8.8) Triton X-100 (0.2\%) and a stackıng gel containing $3 \%$ acrylamide $\left(0.16 \% N, N^{\prime}\right.$-methylene-bisacrylamide) in $125 \mathrm{mM}$ Tris- $\mathrm{HCl}$ (pH 6.8), $0.1 \%$ Triton X-100. The gels were polymerized with $0.02 \%$ ammonium persulfate and 0.02\% TEMED. The electrophoresis buffer contained $25 \mathrm{mM}$ Tris/192 mM glycine ( $\mathrm{pH} 8.3$ ) and $0.1 \%$ Triton X-100. Electrophoresis was carned out with a constant current of $35 \mathrm{~mA}$ over $6 \mathrm{~h}$ (that is about twice the time taken for the marker dye to reach the end of the gel).

Gels were rnsed twice with $20 \mathrm{mM}$ Mops pH 7.0, $1 \mathrm{mM}$ EGTA for $30 \mathrm{~mm}$. Then acetylthiocholine $(0.5 \mathrm{mM})$ and DTNB $(0.5 \mathrm{mM})$ was added. Photography was carred out after maximal development of yellow colour (after approx. $30 \mathrm{~min}$ ).

\section{Results}

\section{Isolation of secretory vesicles}

The distribution of protein, marker substances and enzymes in the subcellular fractions obtained during differential centrifugation of adrenal medullary homogenates is given in Table I. The relative specific activities of enzymes as well as the relative specific concentrations of other substances are given in Table II.

As judged from the amount of lactate dehydrogenase, acetylcholinesterase, adrenalin and ascorbate in the low speed supernatant $S_{1}$ most of the tissue was broken and the homogenization procedure was sufficient to release most of the secretory vesicles. By contrast, the percentage of glutamate dehydrogenase (used as a marker for mitochondria) and of the microsomal marker glucose-6-phosphatase was comparatively lower in $S_{1}$. The presence of a considerable amount of those marker enzymes in the low speed pellet $P_{1}$ suggests that cell types with different enzyme content exist in the tissue which are characterized by different susceptibilities to homogenization.

Pellet $\mathbf{P}_{2}$, which was used for further purification on density gradients, contains mainly secretory vesıcles and mitochondria (41\% of adrenalın, $37 \%$ glutamate dehydrogenase with a relative specific concentration of 3.4 and a relative specific activity of 3.0, respectively). Ascorbic acid, a constituent of secretory vesicles [11] was found not only in pellet $\mathrm{P}_{2}$ (23\%, relative specific concentration 1.9$)$, but also 
TABLE I

DISTRIBUTION OF MARKERS IN FRACTIONS SEPARATED BY DIFFERENTIAL CENTRIFUGATION

\begin{tabular}{|c|c|c|c|c|c|c|c|c|}
\hline \multirow[t]{2}{*}{ Marker } & \multirow{2}{*}{$\begin{array}{l}\text { Number } \\
\text { of expts }\end{array}$} & \multirow{2}{*}{$\begin{array}{l}\text { Homogenate } \\
\text { (absolute values) }^{a}\end{array}$} & \multicolumn{6}{|c|}{ Percentage in fractions } \\
\hline & & & $P_{1}$ & $\mathrm{~S}_{1}$ & $\mathbf{P}_{2}$ & $\mathrm{~S}_{2}$ & $\mathrm{P}_{3}$ & $\mathrm{~S}_{3}$ \\
\hline Protein & 20 & $3309 \pm 0.589$ & $40.5 \pm 5.5$ & $44.2 \pm 8.7$ & $12.2 \pm 3.9$ & $26.2 \pm 4.1$ & $5.9 \pm 1.9$ & $17.8 \pm 2.9$ \\
\hline Ascorbate & 8 & $5.07 \pm 0.87$ & $15.8 \pm 6.5$ & $75.1 \pm 7.5$ & $22.7 \pm 2.1$ & $45.6 \pm 7.3$ & $5.2 \pm 2.6$ & $37.4 \pm 5.7$ \\
\hline Adrenalın & 20 & $79.9 \pm 10.2$ & $17.1 \pm 2.9$ & $74.9 \pm 13.9$ & $40.8 \pm 7.5$ & $25.4 \pm 4.2$ & $9.9 \pm 3.2$ & $14.2 \pm 3.2$ \\
\hline Glutamate dehydrogenase & 8 & $0.012 \pm 0.004$ & $54.4 \pm 7.8$ & $51.6 \pm 8.7$ & $36.5 \pm 5.9$ & $5.9 \pm 1.3$ & $3.5 \pm 0.8$ & $2.5 \pm 1.6$ \\
\hline Glucose-6-phosphatase & 10 & $0.70 \pm 0.12$ & $88.0 \pm 15.9$ & $31.0 \pm 6.2$ & $9.7 \pm 1.8$ & $18.1 \pm 2.7$ & $6.4 \pm 1.3$ & $2.8 \pm 1.6$ \\
\hline Acetylcholinesterase & 9 & $0.023 \pm 0.006$ & $32.7 \pm 6.8$ & $62.6 \pm 9.2$ & $17.3 \pm 4.2$ & $36.2 \pm 6.7$ & $19.9 \pm 6.0$ & $9.5 \pm 4.6$ \\
\hline Lactate dehydrogenase & 10 & $0.172 \pm 0.028$ & $18.6 \pm 6.0$ & $796 \pm 12.3$ & $2.7 \pm 1.2$ & $72.9 \pm 10.8$ & $2.8 \pm 0.5$ & $65.4 \pm 7.2$ \\
\hline
\end{tabular}

a Protein is given as g measured in the homogenate of $48 \mathrm{~g}$ tissue (wet weight), ascorbate and adrenalın as $\mu \mathrm{g} / \mathrm{mg}$ protein, lactate and glutamate dehydrogenase as $\mu \mathrm{mol} \mathrm{NADH} \mathrm{oxidıed/min} \mathrm{per} \mathrm{mg} \mathrm{protein,} \mathrm{dcetylcholınesterase} \mathrm{as} \mu \mathrm{mol}$ acetylthiocholıne hydrolyzed $/ \mathrm{min}$ per mg protein, glucose-6-phosphatase as $\mu$ mol phosphate released $/ \mathrm{h}$ per mg protein. Values are means $\pm \mathrm{S}$ D. Percentages of marker in fractions are given with respect to the homogenate. 
TABLE II

RELATIVE SPECIFIC ACTIVITIES (OR CONCENTRATIONS) OF MARKER IN FRACTIONS SEPARATED BY DIFFERENTIAL CENTRIFUGATION

\begin{tabular}{|c|c|c|c|c|c|c|c|}
\hline \multirow[t]{2}{*}{ Marker } & \multirow{2}{*}{$\begin{array}{l}\text { Number } \\
\text { of expts. }\end{array}$} & \multicolumn{6}{|c|}{ Relative specific activities (or concentrations) of fractions a } \\
\hline & & $P_{1}$ & $S_{1}$ & $\mathbf{P}_{2}$ & $\mathrm{~S}_{2}$ & $\mathbf{P}_{3}$ & $\mathrm{~S}_{3}$ \\
\hline Ascorbate & 8 & $0.39 \pm 0.16$ & $1.69 \pm 0.16$ & $1.86 \pm 0.17$ & $1.74 \pm 0.28$ & $0.88 \pm 0.44$ & $210 \pm 0.32$ \\
\hline Adrenalın & 9 & $0.42 \pm 0.07$ & $1.69 \pm 0.31$ & $3.36 \pm 0.61$ & $0.97 \pm 0.16$ & $1.69 \pm 0.54$ & $0.79 \pm 0.18$ \\
\hline Glutamate dehydrogenase & 8 & $1.34 \pm 0.19$ & $1.17 \pm 0.20$ & $3.00 \pm 0.48$ & $0.22 \pm 0.05$ & $0.59 \pm 0.14$ & $014 \pm 0.09$ \\
\hline Glucose-6-phosphatase & 10 & $2.17 \pm 0.39$ & $0.70 \pm 0.14$ & $0.79 \pm 0.15$ & $0.69 \pm 0.10$ & $1.10 \pm 0.22$ & $0.16 \pm 0.09$ \\
\hline Acetylcholinesterase & 9 & $0.81 \pm 0.17$ & $1.42 \pm 0.21$ & $1.42 \pm 0.34$ & $1.38 \pm 0.26$ & $3.40 \pm 1.02$ & $0.54 \pm 0.26$ \\
\hline Lactate dehydrogenase & 10 & $0.46 \pm 0.15$ & $1.79 \pm 0.28$ & $0.22 \pm 0.09$ & $2.94 \pm 0.41$ & $0.48 \pm 0.08$ & $3.68 \pm 0.40$ \\
\hline
\end{tabular}

a Relative specific activity (or concentration) is the ratio of the percent of marker to the percent of protein in a given fraction. Values are means \pm standard devation.

in the particle free supernatant $\mathrm{S}_{3}(37 \%$, relative specific concentration 2.1 ). Since only $14.2 \%$ of the adrenalin remains in $S_{3}$, presumably originating from secretory vesicles damaged during homogenization, it can be concluded that ascorbate exists in the cytoplasm as well as in secretory vesicles. This is in accordance with previous findings [19]. Acetylcholinesterase, chosen as a marker for cell membranes, occurs in equal amounts in pellet $P_{2}$ and $P_{3}$, but is enriched in $\mathrm{P}_{3}$ (relative specific activity 3.4 ).

The isotonic density gradient was designed to separate the secretory vesicles recovered in $\mathbf{P}_{\mathbf{2}}$ mainly from mitochondria as well as from minor contamination by cell membranes and microsomes. The density profile of this gradient was determined by refractive index measurements ( $F_{1}$ g. 1). Two bands ( $A$ and $B$, see also protein distribution in Fig. 1) can be easily distinguished by eye. Band $\mathrm{A}$ which centered around fraction 10 (density $1.105 \mathrm{~g} / \mathrm{ml}$ ) contained the highest amount of adrenalın, noradrenalin and ascorbate, which characterize secretory vesicles. The hump of these substances formed in fractions of lower densities most probably indicates that some vesicles have lost part of their contents during homogenization and/or subfractionation. Glutamate dehydrogenase, glucose-6-phosphatase, lactate dehydrogenase and acetylcholinesterase were found in band B (Fig. 1) indicating that mitochondria, microsomes and rightside-out cell membranes can be removed efficiently from secretory vesicle fractions (band A) in the gradient. Acetylcholinesterase activity used as a marker for cell membranes could not be detected in band $\mathrm{A}$ when the assay was carred out in isotonic media. However, addition of $0.2 \%$ Triton X-100 results in a clear hump of acetylcholinesterase activity in band $\mathrm{A}$ (Fig. 1).

The secretory vesicle fraction (fraction SV) was recovered from the gradient and further analyzed (see Materials and Methods). Fraction SV (Table III) contained $24.9 \%$ of the total adrenalin present in the homogenate, with a relative specific concentration of 5.19 . The amount of adrenalin $(2.26 \pm 0.31 \mu \mathrm{mol} / \mathrm{mg}$ protein, calculated from Table III) and ascorbate $(52 \pm 13 \mathrm{nmol} / \mathrm{mg}$ protein) in the secretory vesicles fraction is in good agreement with the reported data of secretory vesicles obtained by sucrose density gradients (cf. Ref. 20). The composition of the isolated material therefore compares well with the highly purified secretory vesicles recovered from sucrose gradients. Fraction SV did not exhıbit lactate dehydrogenase actıvity and the low percentages as well as the low relative specific activities of glutamate dehydrogenase, glucose-6-phosphatase and acetylcholinesterase characterize the high purity of the secretory vesicle fraction.

\section{Stability of isolated secretory vesicles}

Secretory vesicles (fraction SV) release adrenalin during incubation at $37^{\circ} \mathrm{C}$. Within the first $10 \mathrm{~min}$ of incubation a rapıd leakage was observed followed by a slow steady release. After $60 \mathrm{~min}$ around $80 \%$ of the hormone was still located inside the vesicles (Fig. 2). Changes of pH (between 6 and 8) did not affect the stability of the isolated secretory vesicles. 


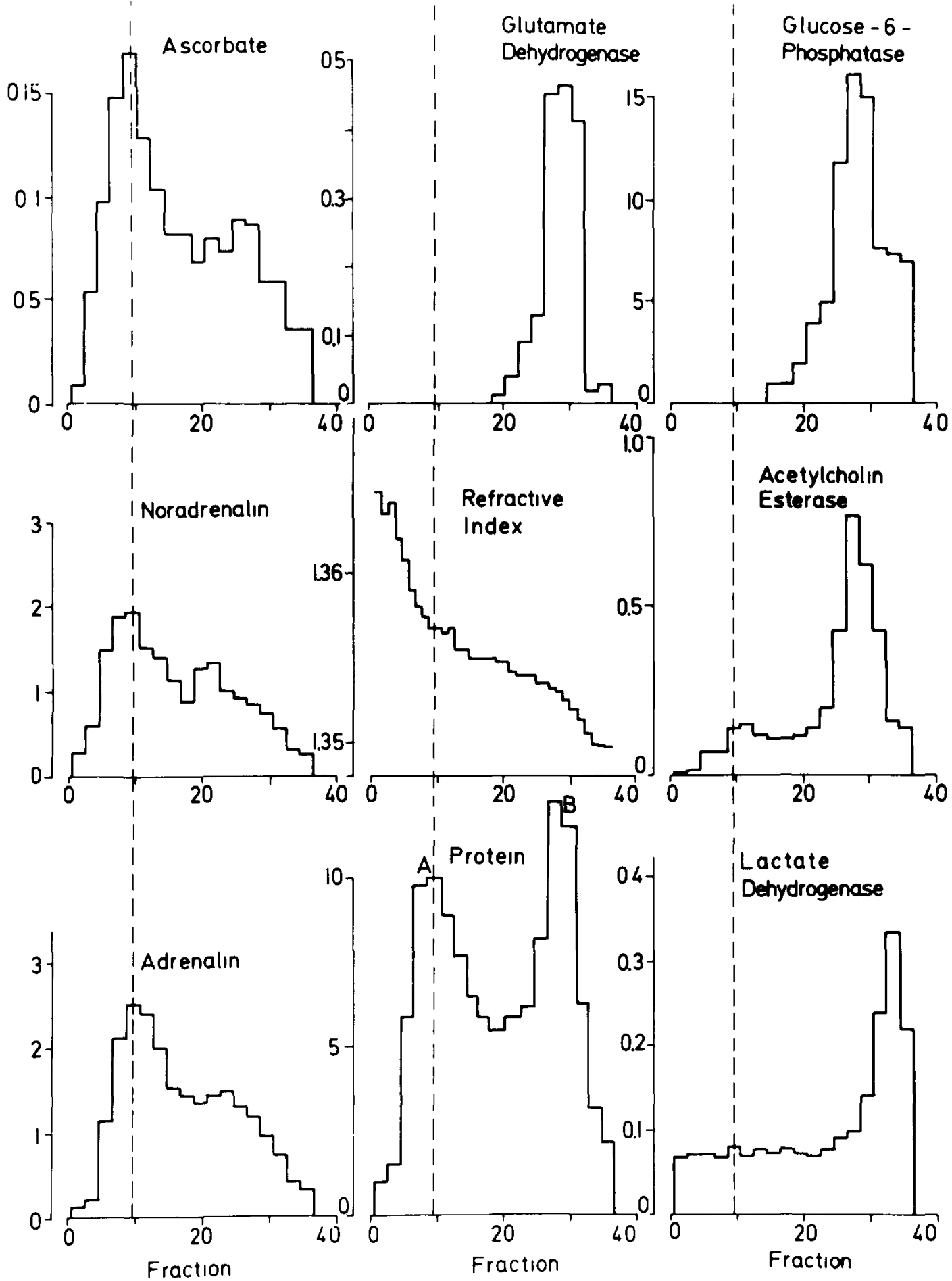

Fig. 1. Distribution of markers in the density gradient. Ascorbate, noradernalın, adrenalin and proteın is given as $\mathrm{mg} / \mathrm{ml}$, lactate and glutamate dehydrogenase as $\mu \mathrm{mol} \mathrm{NADH}$ oxidized/min per $\mathrm{ml}$, acetylcholınesterase as $\mu$ mol acetylthıocholıne hydrolyzed/ $\mathrm{min}$ per $\mathrm{ml}$ and glucose- 6 -phosphatase as $\mu \mathrm{mol}$ phosphate released/h per $\mathrm{ml}$. Lactate, glutamate dehydrogenase, acetylcholınesterase and glucose-6-phosphatase are measured in the presence of Triton X-100. 
TABLE III

DISTRIBUTION OF MARKERS IN FRACTIONS SEPARATED BY DENSITY GRADIENT CENTRIFUGATION

\begin{tabular}{|c|c|c|c|c|c|}
\hline \multirow[t]{3}{*}{ Marker } & \multirow{3}{*}{$\begin{array}{l}\text { Number } \\
\text { of expts. }\end{array}$} & \multicolumn{2}{|c|}{ Percentage in fraction a } & \multicolumn{2}{|c|}{$\begin{array}{l}\text { Relative specific activities } \\
\text { (or concentrations) } b\end{array}$} \\
\hline & & \multirow[t]{2}{*}{ SV } & \multirow[t]{2}{*}{$\mathrm{R}$} & & \\
\hline & & & & SV & $\mathbf{R}$ \\
\hline Protein & 20 & $4.8 \pm 0.8$ & $5.5 \pm 0.8$ & & \\
\hline Ascorbate & 9 & $7.9 \pm 3.0$ & $6.7 \pm 2.1$ & $1.84 \pm 0.69$ & $1.36 \pm 0.42$ \\
\hline Adrenalın & 20 & $24.9 \pm 4.5$ & $16.2 \pm 2.6$ & $5.19 \pm 0.67$ & $3.04 \pm 0.95$ \\
\hline Glutamate dehydrogenase & 9 & $1.4 \pm 0.7$ & $18.5 \pm 5.9$ & $0.33 \pm 0.17$ & $3.93 \pm 1.26$ \\
\hline Glucose-6-phosphatase & 11 & $0.8 \pm 0.4$ & $3.9 \pm 0.9$ & $0.20 \pm 0.10$ & $0.83 \pm 0.18$ \\
\hline Acetylcholınesterase & 8 & $1.7 \pm 0.6$ & $10.4 \pm 2.5$ & $0.40 \pm 0.13$ & $2.13 \pm 0.52$ \\
\hline Lactate dehydrogenase & 8 & $<0.08$ & $0.8 \pm 0.3$ & $<0.02$ & $0.17 \pm 0.07$ \\
\hline
\end{tabular}

a Percentages of marker in fractions are given with respect to the homogenate.

${ }^{b}$ Relative specific activity (or concentration) is the ratio of marker to the percent of protein in a given fraction. Values ate means $\pm S$ D. Fraction SV (secretory vesicles) are combined fractions $1-18$ from the gradient, fraction $R$ the remaining fractions.

The stability of isolated secretory vesicles over a broad range of osmolalities in buffered sucrose media or buffered $\mathrm{KCl}$ media was determined after $30 \mathrm{~min}$ of incubation at $37^{\circ} \mathrm{C}$ and is shown in Fig. 3. Whereas at osmolalities between 400 and $800 \mathrm{mosmol} / \mathrm{kg}$,

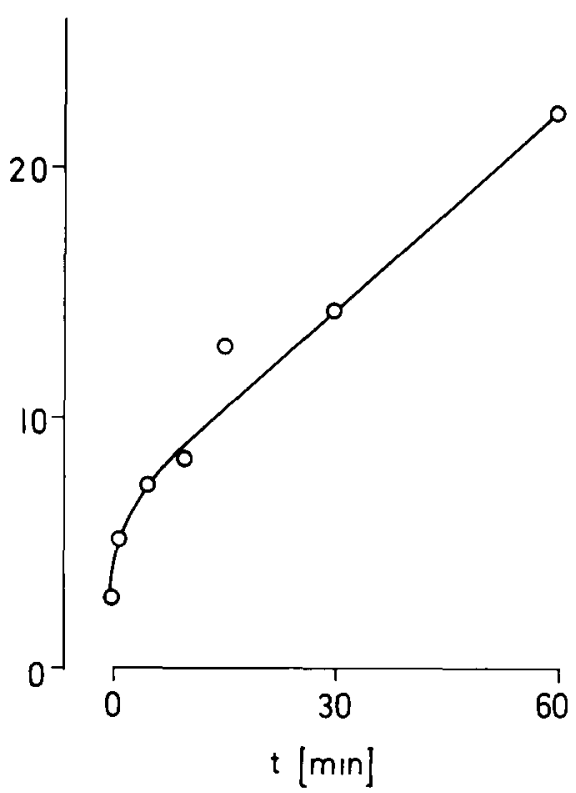

Fig. 2. Stability of isolated secretory vesicles incubated in Mops/sucrose/EGTA medium at $37^{\circ} \mathrm{C}$. Ordınate $\%$ adrenalin released from the vesicles, which were separated by centrifugation. secretory vesicles were equally stable in both types of media, a gradual release of adrenalin was observed below $400 \mathrm{mosmol} / \mathrm{kg}$ which was complete at 150

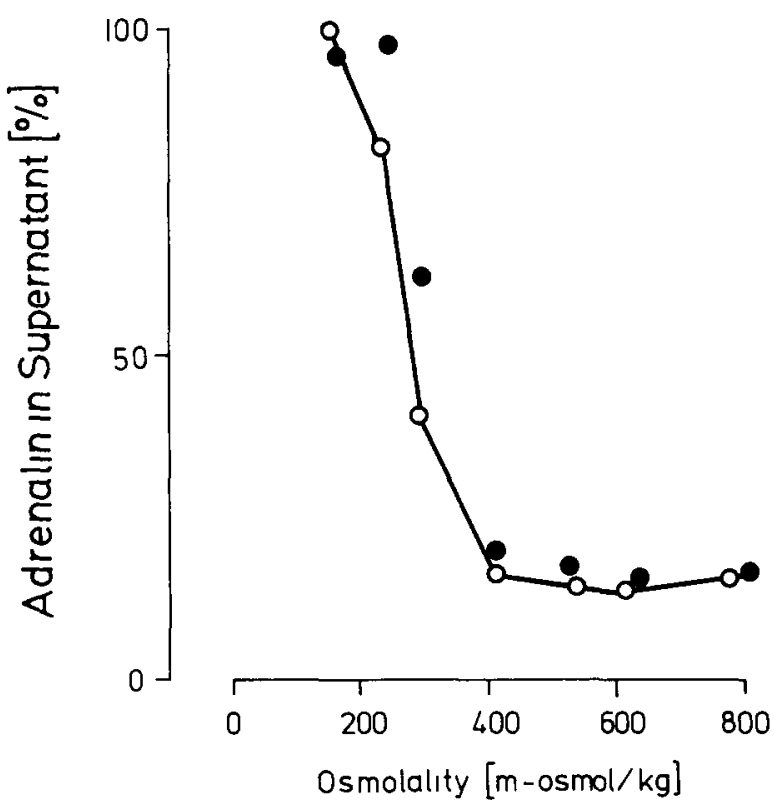

Fig. 3. Percent of adrenalın released from secretory vesicles as a function of osmolality. Vesicles were incubated (30 min, $37^{\circ} \mathrm{C}$ ) in $20 \mathrm{mM}$ Mops, pH 7.0, $1 \mathrm{mM}$ EGTA and various concentrations of sucrose $(0)$ or $\mathrm{KCl}(\bullet)$ to give the osmolalities shown at the abscissa. Ordinate: \% of adrenalin released from the vesicles. 
TABLE IV

RELEASE OF ADRENALIN AND ACETYLCHOLINESTERASE FROM SECRETORY VESICLES IN MEDIA OF DIFFERENT COMPOSITION

Isolated secretory vesicles were incubated for $30 \mathrm{~min}$ at $37^{\circ} \mathrm{C}$ in $20 \mathrm{mM}$ Mops, pH $7.0,1 \mathrm{mM}$ EGTA and sucrose to obtain a final osmolality of $420(\mathrm{mosmol} / \mathrm{kg})$ and the percentage of adrenalın and acetylcholinesterase released into the supernatant was determined (see Methods). The values in parenthesis were obtained replacing sucrose in the Mops/sucrose/EGTA medium by an isosmolal amount of $\mathrm{KCl}$. (Mean of three experiments, n.d., not determıned).

\begin{tabular}{lll}
\hline Addititives & $\begin{array}{c}\text { Adrenalın } \\
\text { 1n supernatant }(\%)\end{array}$ & Acetylcholinesterase in supernatnatant $(\%)$ \\
\hline None & $12.1(14.4)$ & $3.0(4.7)$ \\
$0.2 \mathrm{mM} \mathrm{Mg}^{2+}$ & $14.0(13.6)$ & n.d. (n.d.) \\
$02 \mathrm{mM} \mathrm{Mg}^{2+}+02 \mathrm{mM} \mathrm{ATP}$ & $16.6(12.7)$ & n.d. (n.d.) \\
$2 \mathrm{mM} \mathrm{Mg}^{2+}$ & $10.4(12.3)$ & $2.9(4.9)$ \\
$2 \mathrm{mM} \mathrm{Mg}$ & $8.2(61.8)$ & $2.6(23.6)$ \\
$1.1 \mathrm{mM} \mathrm{Ca}^{2+}$ & 16.3 (n.d.) & n.d. (n.d.) \\
\hline
\end{tabular}

mosmol $/ \mathrm{kg}$. The release below $400 \mathrm{mosmol} / \mathrm{kg}$ was slightly higher in $\mathrm{KCl}$ media. Addition of $\mathrm{MgCl}_{2}(0.2$ or $2 \mathrm{mM}), \mathrm{CaCl}_{2}(1.1 \mathrm{mM})$, or $0.2 \mathrm{mM} \mathrm{MgCl}_{2}$ plus $0.2 \mathrm{mM} \mathrm{ATP}$, in sucrose media or $\mathrm{KCl}$ media, respectively, did not increase the release of hormone from the vesicles. However, $2 \mathrm{mM} \mathrm{MgCl}_{2}$ plus $2 \mathrm{mM}$ ATP in $\mathrm{KCl}$ medıa resulted in a considerable loss of intravesicular adrenalın (Table IV).

\section{Acetylcholinesterase in isolated secretory vesicles}

Acetylcholinesterase could hardly be detected when assayed in isolation medium ( $420 \mathrm{mosmol} / \mathrm{kg}$ ), even in concentrated fractions of secretory vesicles (Fig. 4). However, addition of $0.2 \%$ Triton X-100 resulted in a marked increase in enzyme activity. Similarly, reduction of the osmolality produced a gradual increase in enzyme activity (Fig. 4). On reduction of the osmolality of the media to $40-150$ mosmol $/ \mathrm{kg}$ about half of the activity observed after addition of Triton X-100 had arisen within 2 min. To find out whether or not acetylcholinesterase is released from the vesicle contents during hypotonic treatment, secretory vesicles were centrifuged and the percentage of enzyme released was determined in the supernatant (Fig. 5). An increased percentage of acetylcholinesterase became soluble on decreasing the osmolalities of the incubation media. At osmolalities around 100 mosmol $/ \mathrm{kg}$ nearly $40 \%$ of the total acetylcholinesterase present in secretory vesicles was found in the supernatant. Obviously a membrane-

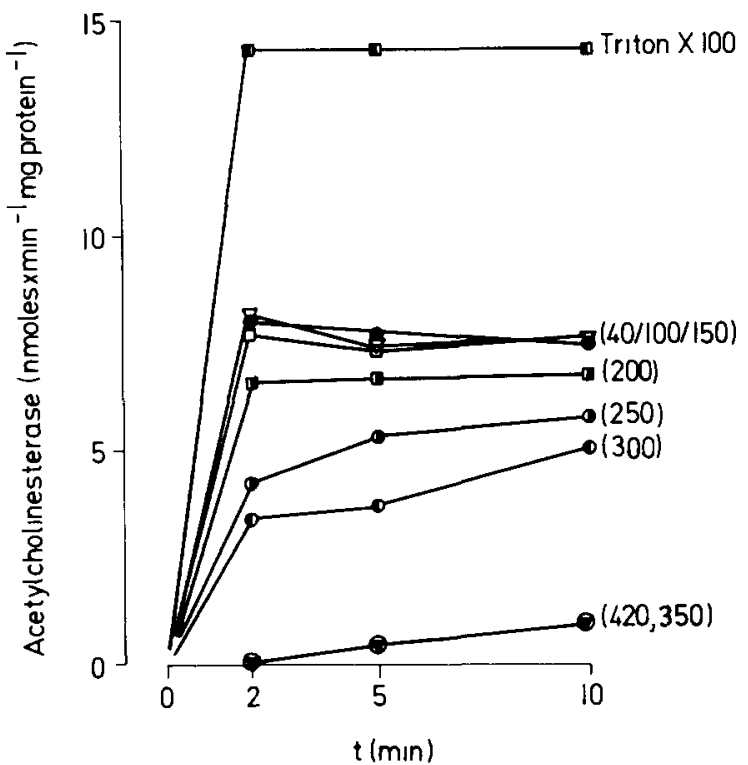

Fig. 4. Increase of acetylcholnesterase activity in secretory vesicles after addition of Triton $\mathrm{X}-100$ and in hypotonic media. Isolated secretory vesicles in Mops/sucrose/EGTA medium were diluted at time 0 at room temperature with 20 $\mathrm{mM}$ Mops, pH 7.0, $1 \mathrm{mM}$ EGTA and sucrose to give the osmolalities shown in brackets. Acetylcholinesterase activity was determined at the times indicated in the dual wave length mode $(412 \mathrm{~nm} / 450 \mathrm{~nm})$. Total enzyme activity in secretory vesicles was determined with Triton $\mathrm{X}-100$ (0.2\% final concentration) present. 


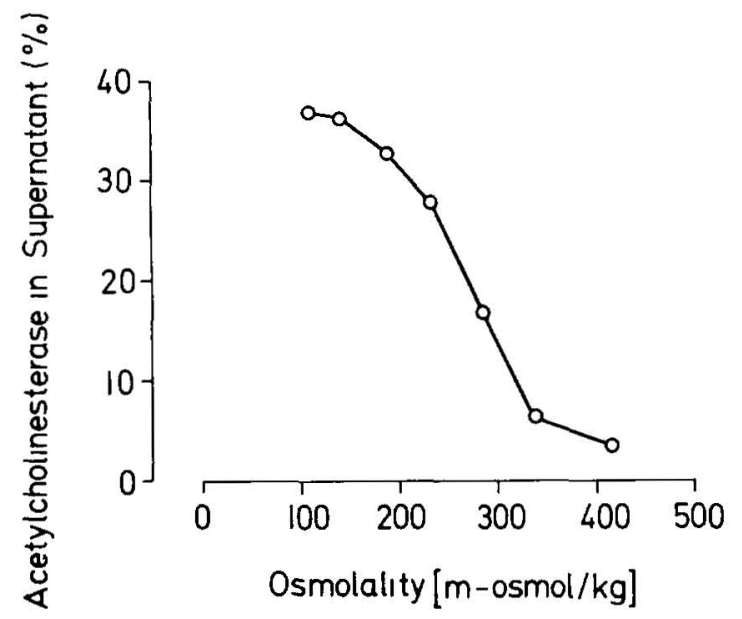

Fig. 5. Release of acetylcholinesterase from secretory vesicles as a function of osmolality. Vesicles were incubated $(30 \mathrm{~min}$, $37^{\circ} \mathrm{C}$ ) in $20 \mathrm{mM}$ Mops, pH 7.0, $1 \mathrm{mM}$ EGTA and various concentrations of sucrose to give the osmolalities shown on the abscissa. Ordinate Percent of total acetylcholinesterase released into the supernatant.

bound pool of acetylcholinesterase exists in isolated adrenal medullary secretory vesicles as well as a soluble pool.

As shown in Fig. 6 the soluble enzyme present in the vesicle contents exhibits the same electrophoretic mobility as the enzyme found in the perfusate from stımulated adrenal glands (perfusion and stımulation with carbachol of.glands was carried out as described [3]). In the vesicle membranes (ghosts) two types of acetylcholinesterase could be detected using polyacylamide gel electrophoresis in the presence of Triton $\mathrm{X}-100$. One type was identical in 1ts mobility with the enzyme present in the vesicle contents (probably this fraction is incompletely released during hypotonic lysis). A second type, with different mobility most likely represents the membrane-bound form of acetylcholinesterase within secretory vesicles. Therefore the difference in enzyme activity found after addition of Triton X-100 and during hypotonic treatment (Fig. 4 ) is not solely due to the membrane-bound form of acetylcholinesterase but also contains contributions from soluble acetylcholinesterase trapped within secretory vesicle ghosts.

In contrast to acetylcholinesterase, small molecules (e.g adrenalin) can be released completely from ssolated adrenal medullary secretory vesicles during

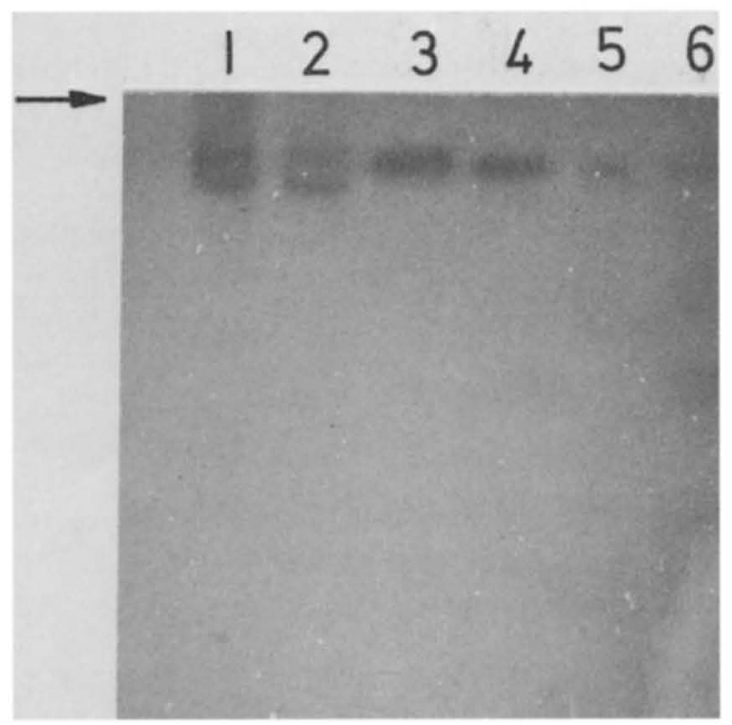

Fig 6. Polyacrylamide gels demonstrating acetylcholınesterase activity. The protein migrated from the top (arrow, start) to the bottom, which was the anode; Slots $1+2$. Secretory vesicle ghosts; Slots $3+4$. Secretory vesicle content; Slots $5+6$ : Perfusate of adrenal glands, collected after stımulation with carbachol.

hypotonic treatment (Fig. 3). In isotonic incubation media containıng $\mathrm{KCl}$, soluble vesicle contents can also be released specifically from secretory vesicles with $2 \mathrm{mM} \mathrm{Mg}^{2+} /$ ATP (Table IV). Concomitantly with the hormone $(62 \%)$ a proportional percentage of acetylcholinesterase (25\%) (compared to $40 \%$ released maximally by hypotonic treatment (see Fig. 5)) is released from the vesicles. Also $37 \%$ of the total protein of secretory vesicles is found in the supernatant (not shown in Table IV).

\section{Discussion}

The secretory vesicles fraction isolated by differential and isosmolal density gradient centrifugation as described here compares well with the highly purified secretory vesicles recovered from sucrose gradients judging from its specific activities of fraction const1tuents and marker enzymes, (see Results, compare with Ref. 20). One major advantage of the procedure presented here is that the secretory vesicles were not exposed to hypertonic sucrose in gradients, which could have caused the instability of such vesicles. To minimize alterations of membrane properties and the 
loss of intravesicular contents, sucrose has been replaced previously by Ludox silica [21], sucroseFicoll- ${ }^{2} \mathrm{H}_{2} \mathrm{O}$ [22], sucrose-metrizamide [23] and polyvinylpyrrolidone-coated slica $\quad\left(\right.$ Percoll $^{\mathrm{TM}}$ ) [24-26].

However, in all the aforementioned investigations, 'crude' secretory vesicle fractions isolated by differential centrifugation and then put onto isosmolal gradients, were isolated in $0.25-0.3 \mathrm{M}$ sucrose media. Since the vesicles tend to lyze in such media (Fig. 3) such further purification of the material on isosmolal gradients is of limited value (e.g. in one of these investigations, where numerical values of the specific content of adrenalin in the subcellular fractions purified by differential centrifugation as well as gradient centrifugation are given [26], the secretory fraction recovered from a Percoll gradient actually contains only 1.5-times more adrenalin per $\mathrm{mg}$ protein than the homogenate). Consequently the amount of adrenalin per $\mathrm{mg}$ of protein in the secretory vesicles was only $1 / 5$ of that found in this study (see Results) or in secretory vesicles recovered from sucrose gradients [20]. Also, compared to the conventional sucrose step gradient, the relative specific content of vesicular ATP is not increased during further purification on sucrose-metrizamide or on sucrose-Ficoll${ }^{2} \mathrm{H}_{2} \mathrm{O}$ gradients (see Fig. 4 in Ref. 23). A direct comparison of the purity of secretory vesicles isolated in sucrose-Ficoll- ${ }^{2} \mathrm{H}_{2} \mathrm{O}$ gradients, in sucrose gradients or in Percoll gradients shows that mitochondrial contamination is less in the latter than in either of the other preparations [26]. Since secretory vesicles in Ludox silica gradients overlap with mitochondria [21] only Percoll gradients are suitable to remove mitochondria and other contaminants from adrenal medullary vesicles isolated by differential centrifugation [24-26].

In addition to the high purity of the secretory vesicles isolated as described in this report, the stability of the vesicles is superior to other preparations. As observed in many laboratories further purification of secretory vesicles on sucrose density gradients gives rise to great fragility when incubated at $37^{\circ} \mathrm{C}$. Even for secretory vesicles isolated only by differential centrifugation leakage during incubation in $300 \mathrm{mM}$ sucrose media was found to be much higher [27] than leakage from vesicles purified further on Percoll gradients (Fig. 2). Secretory vesicles further purified on sucrose-metrizamide gradients incubated at $37^{\circ} \mathrm{C}$ in $300 \mathrm{mM}$ sucrose release about $50 \%$ of their content within $5 \mathrm{~min}$, followed by a slow further release over the next hour [28]. By contrast secretory vesicles recovered from Percoll gradients release only $7.5 \%$ of total adrenalın after $5 \mathrm{~min}$ of incubation at $37^{\circ} \mathrm{C}$, with a gradual release of further content withın $1 \mathrm{~h}$ (F1g. 2).

It is reasonable to assume, that the observed stability of the secretory vesicles preparation obtained as described in this work, is due manly to the maintanance of an osmolality of about $420 \mathrm{mosmol} / \mathrm{kg}$ throughout the isolation procedure, since the lower osmolalities used in the other procedures causes considerable leakage (Fig. 3). The sensitivity of secretory vesicles to changes in osmolality has also been observed by other workers $[29,30]$.

$\mathrm{Ca}^{2+}$, which causes fusion of isolated adrenal medullary secretory vesıcles, or $\mathrm{Mg}^{2+}$, which cannot induce fusion at the concentrations used here [31-33], do not affect the stability of isolated secretory vesicles in sucrose- or KCl-media ( $>400 \mathrm{mosmol} /$ $\mathrm{kg}$, Table IV). As was observed earlier with secretory vesicles isolated by differential centrifugation [27], adrenalin is set free by an appropriate concentration of $\mathrm{Mg}^{2+} / \mathrm{ATP}$ in $\mathrm{KCl}$ media but not in sucrose media. This shows, that also highly purified secretory vesicles deplete their contents as a consequence of an ATP driven proton translocation in the presence of a permeant anıon [27].

Acetylcholinesterase was found with its active site sequestered within secretory vesicles (latent). Enzyme activity became patent in hypotonic media or when detergent was added (Fig. 4). Part of the total pool of acetylcholinesterase was soluble within the vesicles (1.e., could be released together with adrenalın by hypotonic treatment, Fig. 5). This soluble fraction, could also be released specifically from secretory vesicles by $\mathrm{Mg}^{2+} / \mathrm{ATP}$, as can adrenalin (Table IV). The electrophoretic mobility of the soluble enzyme was indistinguishable from the enzyme found in the perfusate of bovine adrenal glands stimulated with carbachol. In addition to the soluble enzyme a membrane-bound form of acetylcholinesterase exists within secretory vesıcles. This membrane-bound fraction sediments with the secretory vesicle membranes and exhibits a different electrohoretic mobility compared to the soluble enzyme. A simple conclusion is, 
that the membrane-bound enzyme becomes inserted into the cell membrane, whereas the soluble enzyme present within the vesicles is secreted when secretory vesicles are everted during exocytosis.

$\mathrm{Ca}^{2+}$-dependent secretion of acetylcholinesterase by typical chromaffin cell stimulants has been observed by earlier workers [3]. However, the source as well as the mode of secretion was obscure since the secreted enzyme was absent in a total membrane fraction of adrenal medullary homogenates, but was present in the particle-free supernatant [2]. Attempts to demonstrate acetylcholinesterase in secretory vesicles within chromaffin cells using histochemical technıques have failed [4]. Disregarding possible differences in the sensitivity of histochemical staining compared to direct biochemical analysis, the fallure to detect acetylcholinesterase on the electromicroscopical level may be due to the difficulty in demonstrating an electron-dense reaction product in secretory vesicles containing an electron dense core.

As chromaffin cells myoblasts in culture release soluble acetylcholinesterase into the extracellular fluid, but incorporate membrane-bound acetylcholinesterase (as well as acetylcholine receptor) into the cell membrane, the precursors of which are sequestered within the cells, within membrane-bound organelles [34-37]. A similar relation of enzyme orientation and transport has been found in the hepatocyte for 5 'nucleotidase, which is present on the inner aspect of secretory vesicles membranes as well as on the outer aspect of the cell membrane $[38,39]$.

\section{Acknowledgments}

We thank Mrs. M. Elis for excellent technical assistance and for typing the manuscript and the personnel of the Neunkirchen Public Slaughterhouse for their help in obtaining ox adrenal glands. This work was supported by the Sonderforschungbereich 38 'Membranforschung' of the Deutsche Forschungsgemeinschaft.

\section{References}

1 Palade, G. (1975) Science 189, 347-358

2 Chubb, I.W. and Smith A.D. (1975) Proc. R. Soc. Lond. B $191,245-261$
3 Chubb, I.W. and Smith, A.D. (1975) Proc. R. Soc. Lond. B 191, 263-269

4 Somogyl, P., Chubb, I.W. and Smith, A.D. (1975) Proc. R. Soc. Lond. B 191, 271-283

5 Blakeborough, P. and Louis, C.E. (1980) J. Neurochem. $33,1285-1295$

6 Abbs, M.T. and Phillips, J.H. (1980) Brochım. Biophys. Acta 595, 200-221

7 Gratzl, M., Krieger-Brauer, H. and Ekerdt, R. (1980) Eur. J. Cell Brol. 22, 186

8 Gratzl, M. (1980) in Biological Chemistry of Organelle Formation (Bucher, T, Sebald, W. and Weiss, M., eds.), pp. 165-174, Springer, Berlın, Heidelberg

9 Lowry, O.H., Rosebrough, N.J., Farr, A.L. and Randall, R.J. (1951) J. B1ol. Chem. 193, 265-275

10 Anton, A.A and Sayre, D.F. (1962) J. Pharmacol, Exp. Therap. 138, 360-375

11 Terland, O. and Flatmark, T. (1975) FEBS Lett. 59, 52-56

12 Omaye, S.T., Turnball, J.D. and Sauberhch, H.E (1979) Methods Enzymol. 62, 3-11

13 Schmidt, E. (1974) in Methoden der enzymatischen Analyse (Bergmeyer, H.U., ed.), 3rd edn., pp. 689-696

14 Leıghton, F., Poole, B., Beaufay, H., Baudhuin, P., Coffey, J.W., Fowler, S. and De Duve, C. (1968) J. Cell. Biol. 37, 482-513

15 Lowry, O.H. and Lopez, I. (1946) J. B1ol. Chem. 162, 421-428

16 Ellman, G.L., Courtney, K.D., Andres, V. and Featherstone, R.M. (1961) Biochem. Pharmacol. 7, 88-95

17 Bergmeyer, H.U. and Bernt, E. (1974) in Methoden der enzymatischen Analyse (Bergmeyer, H.U., ed.) 3rd edn., pp. 607-612

18 Laemmli, U.K. (1970) Nature 227, 680-685

19 Ingebretsen, O.C., Terland, O. and Flatmark, T. (1980) Biochım. Biophys. Acta 628, 182-189

20 Winkler, H. (1976) Neuroscience 1, 65-80

21 Lagercrantz, H., Pertoft, H. and Stjarne, L. (1970) Acta Pysiol. Scand. 78, 561-566

22 Trifaro, J.M. and Dworkind, J. (1970) Anal. Biochem. 34, 403-412

23 Morrıs, S.J. and Schovanka, I. (1977) Biochım. Biophys. Acta 464, 53-64

24 Terland, O., Flatmark, T. and Kryvi, H. (1979) Biochım. Biophys, Acta 553, 460-468

25 Meyer, D.I. and Burger, M.M. (1979) J. Biol. Chem. 254, 9854-9859

26 Carty, S.E., Johnson, R.G. and Scarpa, A. (1980) Anal. Biochem. 106, 438-445

27 Casey, R.P., Njus, D., Radda, G.K. and Sehr, P.A. (1976) B1ochem. J. 158, 583-588

28 Morris, S J., Schober, R. and Schultens, E.F. (1977) Biochım. Biophys. Acta 464, 65-81

29 Johnson, R.G. and Scarpa, A. (1976) J. Gen. Physiol. 68, 601-631

30 Creutz, C.E. and Pollard, H.B. (1980) Biophys. J. 31, 255-269 
31 Ekerdt, R., Dahl, G. and Gratzl, M. (1981) Bıochım. Bıophys. Acta 646. 10-22

32 Dahl, G., Ekerdt, R. and Gratzl, M. (1979) Symp. Soc. Exp. B1ol. 33, 349-368

33 Gratzl, M., Schudt, C, Ekerdt, R. and Dahl, G. (1980) in Membrane Structure and Function (Bittar, E.E., ed.), vol, 3, pp. 59-92

34 Famborough, D.M. and Devreotes, P.N. (1978) J. Cell Biol. 76, 237-244
35 Smllowitz, H. (1980) Cell 19, 237-244

36 Rotundo, R.L. and Famborough, D M. (1980) Cell 22, 583-594

37 Rotundo, R.L. and Famborough, D.M. (1980) Cell 22, $595-602$

38 Little, J.S. and Widnell, C.C (1975) Proc. Natl. Acad. Sci. USA 72, 4013-4017

39 Farquar, M.G., Bergeron, J.J.M. and Palade, G.E. (1974) J. Cell Brol, 60, 8-25 